\title{
Impact of sustained-deficit irrigation on tree growth, mineral nutrition, fruit yield and quality of mango in Spain
}

\author{
Víctor Hugo Durán Zuazo ${ }^{1 *}$, Carmen Rocío Rodríguez Pleguezuelo², Dionisio Franco TARIFA ${ }^{3}$
}

\author{
${ }^{1}$ IFAPA Cent. Torres-Tomejil, \\ Carret. Sevilla-Cazalla km 12,2, \\ 41200, Alcalá del Río, Sevilla, \\ Spain, victorh.duran@ \\ juntadeandalucia.es \\ 2 IFAPA Centro Camino \\ de Purchil, Apdo. 2027, \\ 18080 Granada, Spain \\ ${ }^{3}$ Finca "El Zahori", \\ Patron. Cultiv. Subtrop., \\ Plaza de la Constitución 1, \\ Almuñécar (Granada), Spain
}

* Correspondence and reprints

Received 18 August 2010 Accepted 13 January 2011

Fruits, 2011, vol. 66, p. 257-268 (C) 2011 Cirad/EDP Sciences All rights reserved DOI: $10.1051 /$ fruits/2011038 www.fruits-journal.org

RESUMEN ESPAÑOL, p. 268
Impact of sustained-deficit irrigation on tree growth, mineral nutrition, fruit yield and quality of mango in Spain.

Abstract - Introduction. Mango (Mangifera indica L.) is a crop of major economic importance in the provinces of Malaga and Granada (SE Spain). A field experiment on mango trees was designed to determine the optimum irrigation scheduling over three seasons. The aim was to evaluate the impact of sustained-deficit irrigation (SDI) strategies on fruit yield and quality, tree growth, and mineral status under a Mediterranean subtropical climate. Materials and methods. Three sustained-deficit irrigation treatments were applied to mango trees: SDI-1 (33\% ETc), SDI-2 (50\% ETc) and SDI-3 (75\% ETc). The stress treatments were compared with a control (C-100) irrigated at $100 \% \mathrm{ET}_{\mathrm{C}}$. The response of fruit yield, number of fruits, fruit size and quality, and macro- and micronutrients in leaves was determined. Results. The SDI-2 treatment proved to be the most appropriate SDI treatment, since it allowed the trees to reach the highest yield $\left(18.4 \mathrm{t} \cdot \mathrm{ha}^{-1}\right)$ and the best water-use efficiency $\left(7.14 \mathrm{~kg} \cdot \mathrm{m}^{-3}\right)$. However, fruit size was higher for trees of the SDI-3 and C-100 treatments, since they reached significantly higher length and width. The total soluble solids were affected by the SDI treatments only for one year, being highest in fruits from trees of the SDI-1 and SDI-2 treatments. Macro- and micronutrients in the leaves were affected by the SDI treatment only for the P, Mg and Mn contents. Conclusion. The SDI treatment providing $50 \%$ of $\mathrm{ET}_{\mathrm{C}}$ is recommended for mango orchards in order to attain the highest yields and the best water-use efficiency under a Mediterranean subtropical climate.

Spain / Mangifera indica / irrigation / water use / soil water deficit / irrigation rates / fruits / growth / plant nutrition / yields / quality

Impact de l'irrigation à déficit soutenu sur la croissance des arbres, la nutrition minérale, le rendement en fruits, et la qualité de la mangue en Espagne.

Résumé - Introduction. Le manguier (Mangifera indica L.) est une plante de grande importance économique dans les provinces de Malaga et Grenade (sud-est de l'Espagne). Une expérimentation en vergers de manguiers a été conçue pour établir un calendrier d'irrigation optimale programmé sur trois campagnes. L'objectif a été d'évaluer l'impact de stratégies d'irrigation à déficit soutenu (IDS) sur le rendement et la qualité des fruits, la croissance des arbres et le statut minéral des manguiers sous un climat méditerranéen subtropical. Matériel et méthodes. Trois traitements d'irrigation à déficit soutenu ont été appliqués à des manguiers: IDS-1 (33\% de l'ET $\mathrm{C}_{\mathrm{C}}$ ), IDS-2 (50\% de l'ET $\mathrm{C}_{\mathrm{C}}$ ), et IDS-3 (75\% de l'ET $\mathrm{C}_{\mathrm{C}}$ ). Les traitements de stress ont été comparés à un traitement témoin $(\mathrm{C}-100)$ recevant une irrigation correspondant à $100 \% \mathrm{de} \mathrm{ET}_{\mathrm{C}}$. La réponse a été déterminée à partir du rendement et du nombre de fruits, des taille et qualité des fruits, et des macro et micronutriments dans les feuilles. Résultats. Le traitement IDS-2 s'est révélé être le plus approprié, car il a permis d'obtenir le meilleur rendement $\left(18,4 \mathrm{t} \cdot \mathrm{ha}^{-1}\right)$ et la meilleure efficacité d'utilisation de l'eau $\left(7,14 \mathrm{~kg} \cdot \mathrm{m}^{-3}\right)$. Toutefois, le calibre des fruits a été le plus élevé pour les mangues des traitements IDS-3 et C-100, avec des longueurs et largeurs de fruits significativement plus élevées. Les solides solubles totaux ont été affectés par les traitements à déficits soutenus pour seulement une année ; ils ont été les plus élevés pour les traitements IDS-1 et IDS-2. Les macro- et micronutriments dans les feuilles n'ont été affectés par les régimes hydriques que pour les teneurs en $\mathrm{P}, \mathrm{Mg}$ et Mn. Conclusion. En climat méditerranéen subtropical, une irrigation à $50 \%$ de l'ET $\mathrm{C}_{\mathrm{C}}$ doit être recommandée pour les vergers de manguiers en vue d'atteindre les plus hauts rendements et la meilleure efficacité d'utilisation de l'eau.

Espagne / Mangifera indica / irrigation / utilisation de l'eau / déficit hydrique du sol / dose d'irrigation / fruits / croissance / nutrition des plantes / rendement / qualité 


\section{Introduction}

Mango is a highly appreciated fruit throughout the world due to its bright colour, characteristic taste and nutritional value. Native to the Indo-Burmese region, this fruit currently ranks fifth in total production among major fruit crops worldwide. Global production of mangoes is estimated to be over 28.5 Mt per year and it is grown commercially in more than 90 countries. Asia produces $77 \%$ of the world yield, America 13\% and Africa 9\%. In 2005, worldwide exports reached $912,853 \mathrm{t}$, for a total of $543.10 \mathrm{M}$ dollars [1]. Europe imported about 134,258 t of mangos in 2008: this amount increased slightly in comparison with 125,424 t in 2006 [2]. According to projections from the FAO, net imports by the EU will reach $224,000 \mathrm{t}$ in 2014, for an annual increase of $2.5 \%$ [3]. In the case of Spain, cultivation is feasible primarily in the provinces of Granada and Malaga, with some 900 ha of mango orchards soon to exceed a yield of 6,000 t.year ${ }^{-1}$, of which most are Florida cultivars $[4,5]$. In this area, the most extensively produced and commercial cultivar is $\mathrm{cv}$. 'Osteen', with an average weight of $527.1 \mathrm{~g}$, length of $127.1 \mathrm{~mm}$, width of $90.7 \mathrm{~mm}$ and pulp-seed ratio of $88.2 \%$ [6].

Meanwhile, the declining availability of fresh water is becoming a worldwide crisis, worsened by climate change, mainly in the Mediterranean basin, where the climate is characterised by dry summers with high temperatures and evapotranspiration rates, with precipitation commonly concentrated in autumn and winter but largely unpredictable in amount and spatiotemporal distribution. Therefore, the adoption of watersaving strategies by agriculture is becoming increasingly critical, especially under shortage scenarios caused by climate change. Nevertheless, few studies have examined the optimal water supply for subtropical agriculture.

Deficit irrigation signifies that the supplementary water applied is reduced to only a fraction of potential evapotranspiration of a well-watered reference crop $\left(\mathrm{ET}_{\mathrm{C}}\right)$. According to English and Raja, deficit irrigation is an optimisation strategy under which crops are deliberately subjected to some degree of water deficit and yield reduction [7]. An irrigation-deficit strategy can be implemented in various ways, differing mainly in how the water restriction is applied. Particularly, sustained-deficit irrigation (SDI) is based on a uniform water restriction, depending on the crop-water requirements. This approach allows the crop to adapt to the stressful situation. Under a SDI regime, water deficits reduce biomass production under moderate water stress, due to a reduction in canopy size and radiation interception [8].

Irrigation requirement and its effect on mineral nutrition in mango are still not well investigated, especially under a Mediterranean subtropical climate. However, knowledge of the nutrients present in leaves during different stages of the growth and development cycles is essential for determining a tree's nutritional demands [9].

Therefore, the objective of our study was to assess the response of mango trees to sustained-deficit irrigation strategies in terms of fruit yield and quality, tree growth, and mineral status in a Mediterranean subtropical climate (SE Spain).

\section{Materials and methods}

The field experiment was carried out over three seasons (2006-2008) at the experimental farm El Zahorí, near Granada (southeastern Spain) (36 48'00" N, $3^{\circ} 38^{\prime} 0^{\prime}$ " W) and at an elevation of $195 \mathrm{~m}$ (a.s.l.). The study terrace, representative of those commonly found in the area, is a reverse-sloped bench-terrace type averaging (160 to 180) $\mathrm{m}$ long. Each platform had a single row of 12year-old mango trees (Mangifera indica $\mathrm{L}$. cv. 'Osteen' grafted onto 'Gomera-1'), healthy and uniform in size, and spaced $3 \mathrm{~m}$ apart. Under the experimental conditions, a cultivated hectare of mango trees on steeply sloped lands $\left(65^{\circ}\right)$ would have 18 terraces (spaced about $5 \mathrm{~m}$ ) $100 \mathrm{~m}$ long, with an average of 600 trees per ha. Local temperatures are subtropical to semi-hot within the Mediterranean climatic category. The average annual rainfall in the study area is $449.0 \mathrm{~mm}$ and the average temperature is $20.8^{\circ} \mathrm{C}$. The soils of the zone are typical Xerorthent [10], with $684 \mathrm{~g} \cdot \mathrm{kg}^{-1}$ of sand, 
$235 \mathrm{~g} \cdot \mathrm{kg}^{-1}$ of silt and $81 \mathrm{~g} \cdot \mathrm{kg}^{-1}$ of clay, containing $9.4 \mathrm{~g} \cdot \mathrm{kg}^{-1}$ of organic matter, and $0.7 \mathrm{~g} \cdot \mathrm{kg}^{-1}$ of $\mathrm{N}$, with $14.6 \mathrm{mg} \cdot \mathrm{kg}^{-1} \mathrm{P}$ and $178.7 \mathrm{mg} \cdot \mathrm{kg}^{-1}$ assimilable K [11].

Irrigation treatments included three sustained-deficit irrigation (SDI) strategies: SDI1, SDI- 2 and SDI-3 each received 33\%, 50\% and $75 \%$ of ETc, respectively. The control treatment (C-100) received 100\% of the irrigation volume required to meet the crops evapotranspiration demand for the irrigation period. The Penman-Monteith method [12] was used to determine reference evapotranspiration $\left(\mathrm{ET}_{0}\right)$, and crop coefficients $K_{C}$ with the adjustment of tree size were estimated from drainage lysimeters located in the same orchard. The $K_{C}$ values estimated for mango trees during the irrigation period were about $0.51,0.72$ and 0.60 at flowering, fruit set and fruit growth, respectively [13]. Each treatment was applied by a combination of several self-regulating emitters [( 4 and 8) $\left.\mathrm{L} \cdot \mathrm{h}^{-1}\right]$ in a double-line system. Irrigation was controlled automatically by a headunit programmer and electro-hydraulic valves. The amounts of water applied per treatment were measured with flow meters. The experiment was a completely randomised block design with three replications per treatment. Each plot had eight trees per row. The four central trees of the rows were used for fruit yield and tree size measurements and the other four trees served as border trees. The experimental orchard was managed according to commercial practices in the area, with the same fertilisation (240 g N, $71 \mathrm{~g} \mathrm{P}_{2} \mathrm{O}_{5}$ and $212 \mathrm{~g} \mathrm{~K}_{2} \mathrm{O}$ ) and routine cultivation techniques for diseases and insect control.

At harvest, the total fruit yield per tree was registered for each treatment. In the second and third seasons (2007 and 2008), twentyfive fruits per tree were collected to measure vertical and horizontal diameters with a Vernier calliper. In addition, fifteen fruits were selected randomly to evaluate skin, pulp and seed weight percentage. We also determined titratable acidity from fruit juice titrating against $\mathrm{NaOH} 0.05 \mathrm{~N}$ using phenolphthalein as the indicator [14]. Total soluble solids (TSS) $\left({ }^{\circ} \mathrm{Brix}\right)$ were measured by direct reading in a refractometer (Eclipse, Bellingham and Stanley, Ltd.).
In addition, height, canopy diameter and trunk circumference were measured $15 \mathrm{~cm}$ above the bud union in grafted trees. Canopy volume was calculated using the equation for one-half of a proplate spheroid [15]: $C_{V}=4 / 3 \times \pi \times \mathrm{r}^{2} \times 1 / 2 \times \mathrm{H}$, where $C_{V}$ is canopy volume; $r$ is canopy radius; $\mathrm{H}$ is canopy height. Trunk circumference was converted into trunk cross-sectional area: TCSA $=\left[C^{2} /\right.$ $4 \pi$ ], where $C$ is the trunk circumference (cm). Yield efficiency was estimated by dividing fruit yield by canopy volume and by TCSA. Water-use efficiency (WUE) was calculated as fresh mango yield divided by total seasonal irrigation water applied [16].

The soil-water content $(\theta v)$ during the irrigation season was recorded using the Frequency Domain Reflectometry (FDR) system (Diviner-Sentek Pty Ltd.), at (10, 20, 30, 40, 50, 60 and 70) $\mathrm{cm}$ soil depth.

Leaves were chemically analysed after washing and rinsing with distilled water and drying at $70{ }^{\circ} \mathrm{C}$ for $48 \mathrm{~h}$ to constant weight. The $\mathrm{K}, \mathrm{Ca}, \mathrm{Mg}, \mathrm{Fe}, \mathrm{Zn}, \mathrm{Mn}$ and $\mathrm{Cu}$ concentrations were determined by atomic-absorption spectrophotometry [17], while the P concentration was determined by the molybdenum-blue method [18], and total $\mathrm{N}$ by the Kjeldahl method [19].

Data of fruit yield in each season, wateruse efficiency, fruit quality and foliar mineral status were evaluated by analysis of variance, and the means were separated by Tukey's test $(p<0.05)$. In addition, seconddegree polynomial functions were adjusted between fruit yield and amounts of irrigation water.

\section{Results and discussion}

Over the three study years, yields were averaged; in our study area about 600 trees per ha are distributed in terraces and fruit yields were $\left(9.6,18.4,13.5\right.$ and 14.5) $t \cdot \mathrm{ha}^{-1}$ for the SDI-1, SDI- 2 and SDI- 3 treatments and control, respectively. Therefore, the SDI- 2 treatment reached the highest average yield per tree, being significant in comparison with the remaining treatments (table I). Mango trees of SDI-2 produced (1.9, 1.4 and 1.3) times more fruit yield than the SDI-1 
Table I.

Fruit yield and water-use efficiency in response to sustained-deficit irrigations (SDI) and control mango tree orchards (Spain).

\begin{tabular}{|c|c|c|c|c|c|c|c|}
\hline Treatment & $\begin{array}{l}\text { Irrigation } \\
\left(\mathrm{m}^{3} \cdot \operatorname{tree}^{-1}\right)\end{array}$ & $\begin{array}{l}\text { Fruit yield } \\
\left(\mathrm{kg} \cdot \text { tree }^{-1}\right)\end{array}$ & $\begin{array}{l}\text { Number of } \\
\text { fruits per tree }\end{array}$ & $\begin{array}{c}\text { Fruit weight } \\
\text { (g) }\end{array}$ & $\begin{array}{l}\text { Water-use } \\
\text { efficiency } \\
\left(\mathrm{kg} \cdot \mathrm{m}^{-3}\right)\end{array}$ & $\begin{array}{l}\text { Length } \\
(\mathrm{cm})\end{array}$ & $\begin{array}{l}\text { Width } \\
(\mathrm{cm})\end{array}$ \\
\hline \multicolumn{8}{|l|}{ Irrigation treatment } \\
\hline SDI-1 (33\% ETC) & 2.80 & $16.0 \mathrm{a}$ & $28.3 a$ & $536.9 \mathrm{a}$ & $5.7 \mathrm{ab}$ & $13.1 \mathrm{a}$ & $8.6 \mathrm{a}$ \\
\hline SDI-2 (50\% ETC) & 4.30 & $30.7 \mathrm{~b}$ & $53.7 \mathrm{~b}$ & $568.5 \mathrm{ab}$ & $7.1 \mathrm{~b}$ & $13.6 \mathrm{ab}$ & $8.9 \mathrm{a}$ \\
\hline SDI-3 (75\% ETC) & 5.76 & $22.5 a b$ & $36.5 \mathrm{ab}$ & $626.8 \mathrm{bc}$ & $3.9 \mathrm{a}$ & $13.8 b$ & $9.1 \mathrm{ab}$ \\
\hline C-100 (100\% ETC) & 7.91 & $24.1 \mathrm{ab}$ & $39.8 \mathrm{ab}$ & $648.4 \mathrm{c}$ & $3.1 \mathrm{a}$ & $14.1 \mathrm{~b}$ & $9.5 \mathrm{~b}$ \\
\hline \multicolumn{8}{|l|}{ Year } \\
\hline 2006 & & $19.6 \mathrm{a}$ & $38.4 a b$ & $522.8 \mathrm{a}$ & $4.4 \mathrm{a}$ & No data & No data \\
\hline 2007 & & $20.1 \mathrm{a}$ & $29.4 \mathrm{a}$ & $680.1 \mathrm{c}$ & $4.6 \mathrm{a}$ & $14.3 \mathrm{a}$ & $9.7 \mathrm{a}$ \\
\hline 2008 & & $28.9 \mathrm{~b}$ & $49.9 \mathrm{~b}$ & $582.5 \mathrm{~b}$ & $6.1 \mathrm{a}$ & $13.0 \mathrm{~b}$ & $8.3 \mathrm{~b}$ \\
\hline \multicolumn{8}{|l|}{ ANOVA } \\
\hline Irrigation treatment & & * & * & * & * & * & * \\
\hline Year & & * & * & * & ns & * & * \\
\hline Interaction & & ns & ns & ns & ns & * & ns \\
\hline
\end{tabular}

and SDI-3 treatments, and control, respectively. By comparing the study years, the third year registered the highest fruit yield. Yield per tree in our experiment generally proved to be much lower than those reported by Avilán et al. [20] in Venezuela for cvs. Kent and Smith (378-868 kg.tree $\left.{ }^{-1}\right)$. It should be taken into consideration that the coast of Granada and Malaga represent the climatic limit for commercially viable mango cultivation and, therefore, tree sizes and yields are much lower [21], but at highdensity planting. In this context, Spreer et al. [22] found, in a tropical climate, yields for cv. Chok Anan in an experiment of partial root drying and regulated deficit irrigation of (80.9 and 80.2) $\mathrm{kg} \cdot$ tree $^{-1}$, respectively. However, due to the different planting patterns, the yields (9-18 $\mathrm{t} \cdot \mathrm{ha}^{-1}$ ) reached in our present experiment are in a good range with respect to those from typical mango-producing areas, as reported by Pavel and Villers [23] (5-9 t $\left.\cdot \mathrm{ha}^{-1}\right)$, Spreer et al. [22, 24] (4$\left.20 \mathrm{t} \cdot \mathrm{ha}^{-1}\right)$, da Campos et al. [25] $\left(30 \mathrm{t} \cdot \mathrm{ha}^{-1}\right)$, and Litz [26] (22 th ha $\left.{ }^{-1}\right)$.

In terms of the average number of fruits per tree, the SDI-2 treatment consistently resulted in higher amounts of fruits than the other treatments. However, in our study, average fruit weight reached the highest in control trees, which differed significantly from the other treatments (table I). Therefore, differences in yield were influenced by the number of fruits as well as by the fruit size. However, fruit yield correlated mainly with the number of fruits harvested $\left(y=0.50 x+3.36 ; R^{2}=0.91\right)$ and not with the average fruit weight $\left(R^{2}=0.04\right)$. These results are in agreement with those of Spreer et al. [22]. Average fruit weight ranged from (536.9 to 648.4) $\mathrm{g}$ for the SDI-1 treatment and control, respectively. Therefore, mean fruit weight increased with higher irrigation amounts, control trees producing the heaviest fruits and differing significantly from the remaining treatments.

The total water applied in the orchard terraces for the SDI- 1 , SDI- 2 and SDI- 3 treatments, and the control was $(1,680,2,580$, $3,420$ and 4,740$) \mathrm{m}^{3} \cdot \mathrm{ha}^{-1}$, respectively. Consequently, the best sustained-deficit irrigation strategy (SDI-2) in terms of fruit yield saved about $2,160 \mathrm{~m}^{3} \cdot \mathrm{ha}^{-1}(\sim 56 \%)$ in relation to the well-irrigated mango trees. 
The water-use efficiency (WUE) values were significantly influenced by the irrigation treatment $(p<0.05)$, ranging from $3.1 \mathrm{~kg} \cdot \mathrm{m}^{-3}$ in control to $7.1 \mathrm{~kg} \cdot \mathrm{m}^{-3}$ in the SDI-2 treatment (table I). Therefore, WUE was significantly higher in the SDI-2 treatment than in the rest of the treatments, and lower with increasing amounts of irrigation water. Similar results for mango were found in irrigation trials by Pavel and Villiers [23], and Spreer et al. [22]. Consequently, increasing the water amount in mango cv. Osteen did not result in higher yields or WUE, as has also been pointed out by da Campos et al. with mango cv. Tommy Atkins [25]. Therefore, in relation to the regression between fruit yield of the treatments and the overall water consumption from irrigation, we found a good fit to a binomial yield function for the three study years (figure 1). When the three study years were taken into account, the fit to a binomial function was also $\operatorname{good}\left(y=-3.42 x^{2}+32.34 x-47.13\right.$; $\left.R^{2}=0.85\right)$. As can be seen, the optimum level of irrigation would be approximately from (4.5 to 5.5$) \mathrm{m}^{3} \cdot$ tree $^{-1}$, which would correspond mainly to the SDI-2 treatment. These types of binomial functions relating yield and irrigation water have also been estab-

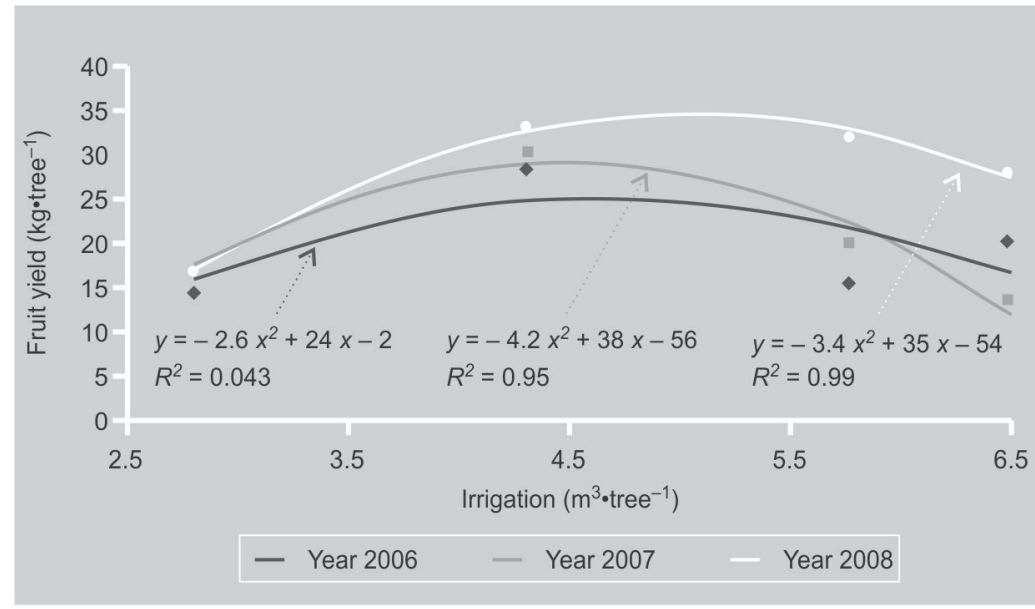

lished for other types of crops [27, 28] as well Figure 1. as for mango [22].

Production functions for the

The results for tree size in the four irriga- study period (2006-2008) tion treatments revealed that control trees comparing fruit yield and had the highest trunk cross-sectional area applied water. Each point $\left(136 \mathrm{~cm}^{2}\right)$ and one of the highest tree heights $(2.9 \mathrm{~m})$ and canopy volumes $\left(13.9 \mathrm{~m}^{3}\right)$ (table $\left.I I\right)$. Therefore, the higher irrigation amount in control trees was invested in vegetative growth rather than in fruit yield. By contrast, trees of the SDI-1 treatment reached the lowest canopy represents the average of 16 studied trees at different levels of sustained-deficit irrigations and control (mango trees, Spain).

Table II.

Tree size and yield efficiency for the sustained-deficit irrigations (SDI) and control mango tree orchards (Spain).

\begin{tabular}{|c|c|c|c|c|c|c|}
\hline \multirow[t]{2}{*}{ Treatment } & \multirow{2}{*}{$\begin{array}{l}\text { Trunk cross-sectional area } \\
\qquad\left(\mathrm{cm}^{2}\right)\end{array}$} & \multirow{2}{*}{$\begin{array}{l}\text { Canopy diameter } \\
\qquad(\mathrm{m})\end{array}$} & \multirow{2}{*}{$\begin{array}{l}\text { Tree height } \\
\text { (m) }\end{array}$} & \multirow{2}{*}{$\begin{array}{l}\text { Canopy volume } \\
\qquad\left(\mathrm{m}^{3}\right)\end{array}$} & \multicolumn{2}{|c|}{ Yield efficiency } \\
\hline & & & & & $\left(\mathrm{g} \cdot \mathrm{cm}^{-2}\right)$ & $\left(\mathrm{kg} \cdot \mathrm{m}^{-3}\right)$ \\
\hline \multicolumn{7}{|l|}{ Irrigation } \\
\hline SDI-1 (33\% ETC) & $103.4 \mathrm{ab}$ & $2.6 \mathrm{a}$ & $2.5 \mathrm{a}$ & $8.9 \mathrm{a}$ & $215.2 \mathrm{a}$ & $2.6 \mathrm{a}$ \\
\hline SDI-2 (50\% ETC) & $127.2 \mathrm{bc}$ & $3.0 \mathrm{~b}$ & $2.9 \mathrm{~b}$ & $13.8 \mathrm{~b}$ & $219.8 \mathrm{a}$ & $2.5 \mathrm{a}$ \\
\hline SDI-3 (75\% ETC) & $96.0 \mathrm{a}$ & $3.0 \mathrm{ab}$ & $2.8 \mathrm{ab}$ & $13.7 \mathrm{~b}$ & $268.8 \mathrm{a}$ & $1.7 \mathrm{ab}$ \\
\hline C-100 (100\% ETC) & $136.0 \mathrm{c}$ & $3.0 \mathrm{ab}$ & $2.9 \mathrm{~b}$ & $13.9 \mathrm{~b}$ & $171.2 \mathrm{a}$ & $1.3 \mathrm{~b}$ \\
\hline \multicolumn{7}{|l|}{ Year } \\
\hline 2007 & $101.8 \mathrm{a}$ & $2.8 \mathrm{a}$ & $2.7 \mathrm{a}$ & $11.4 \mathrm{a}$ & $215.7 \mathrm{a}$ & $1.8 \mathrm{a}$ \\
\hline 2008 & $129.6 \mathrm{~b}$ & $3.0 \mathrm{~b}$ & $2.8 \mathrm{~b}$ & $13.8 \mathrm{~b}$ & $221.8 \mathrm{~b}$ & $2.2 \mathrm{a}$ \\
\hline \multicolumn{7}{|l|}{ ANOVA } \\
\hline Irrigation treatment & * & * & * & * & ns & * \\
\hline Year & * & * & * & * & ns & ns \\
\hline Interaction & ns & ns & ns & ns & ns & ns \\
\hline
\end{tabular}

*, Significant at $p<0.05 ; \mathrm{ns}$, not significant.

Different letters within the same column are statistically different by Tukey's test $(p<0.05)$ 
diameter $(2.6 \mathrm{~m})$, tree height $(2.5 \mathrm{~m})$ and canopy volume $\left(8.9 \mathrm{~m}^{3}\right)$. In terms of yield efficiency, the following trend was identified: SDI-3 treatment $>$ SDI-2 treatment $>$ SDI-1 treatment $>$ control. However, the differences were not statistically significant (table II). Meanwhile, yield efficiency presented the following pattern: SDI-1 treatment $=$ SDI -2 treatment $\approx$ SDI- 3 treatment $>$ control. Therefore, irrigation of control trees was again the least efficient treatment in relation to the yield efficiency for tree size.

Results of the ANOVA for volumetric water content $\left(\theta_{V}\right)$ at each soil depth, comparing the irrigation treatments applied, showed that the irrigation treatment for control trees (C-100) differed significantly from the other treatments, registering the highest soil water content at all depths (table III). The $\theta_{V}$ in the SDI-2 and SDI-3 treatments did not significantly differ from one another at all the registered depths, except for $10 \mathrm{~cm}$, where soil of the SDI-2 treatment reached higher $\theta_{V}$ than soil of the SDI-3 treatment. Soil-water content for the entire profile and each treatment was generally the greatest for $30-40 \mathrm{~cm}$ in depth, and then tended to diminish at $60-70 \mathrm{~cm}$ in depth, except for soil of C-100, which peaked at $\theta_{V}$ at $60 \mathrm{~cm}$ in depth. For the entire irrigation season period, soil of C-100 had the highest water content of all the treatments, followed by soil of the SDI-3, SDI- 2 and SDI- 1 treatments. Also, $\theta_{V}$ was more regular in soil of the C-100 and SDI-1 treatments than in soil of the SDI-2 and SDI-3 treatments, these latter two being significantly influenced by time period (month), since there was a decrease in $\theta_{V}$ of the SDI-2 and SDI- 3 treatments during maximum evapotranspirative demand (June-August) in both years.

Results for the ANOVA for the response of macro- and micronutrient concentration of leaves to sustained-deficit irrigation strategies and control trees at each phenological stage during the last two years of the experiment showed that, regarding nitrogen $(\mathrm{N})$, no significant effect of the irrigation treatment was found in relation to the average concentration of this element (table IV). However, nitrogen concentration changed significantly with the phenological stage, decreasing during the flowering and postharvest periods $(1.60 \%$ and $1.53 \%$, respectively); these results are in agreement with those of Ponchner et al. [29]. At dormancy, we registered a lower amount of $\mathrm{N}$, a finding consistent with the results of Stassen and Janse van Vuuren [30], and contrary to those of Avilán [31], who found higher N concentrations in this period than at any other phenological stage. The flowering process lowered the $\mathrm{N}$ concentration, probably due to enzymatic activity and hormone synthesis, which prompted the production of carbohydrates needed for cell division and elongation in the new spring shoots, to which nitrogenous compounds were directed from mature leaves [32]. The $\mathrm{N}$ concentration in this study ranged from $1.53 \%$

\section{Table III.}

Average volumetric soil-water content (\%) according to different sustained-deficit irrigation (SDI) at different soil depths in mango tree orchards (Spain).

\begin{tabular}{|c|c|c|c|c|}
\hline $\begin{array}{l}\text { Depth } \\
(\mathrm{cm})\end{array}$ & $\begin{array}{c}\mathrm{SDI}-1 \\
\left(33 \% \mathrm{ET}_{\mathrm{C}}\right)\end{array}$ & $\begin{array}{c}\text { SDI-2 } \\
\left(50 \% \mathrm{ET}_{\mathrm{C}}\right)\end{array}$ & $\begin{array}{c}\text { SDI-3 } \\
\left(75 \% \mathrm{ET}_{\mathrm{C}}\right)\end{array}$ & $\begin{array}{c}\mathrm{C}-100 \\
\left(100 \% \mathrm{ET}_{\mathrm{C}}\right)\end{array}$ \\
\hline 10 & $9.1 \mathrm{a}$ & $7.8 \mathrm{a}$ & $12.8 \mathrm{~b}$ & $14.2 \mathrm{~b}$ \\
\hline 20 & $12.9 \mathrm{a}$ & $18.4 \mathrm{~b}$ & $18.9 \mathrm{~b}$ & $23.8 \mathrm{c}$ \\
\hline 30 & $14.5 \mathrm{a}$ & $20.0 \mathrm{~b}$ & $20.0 \mathrm{~b}$ & $23.9 \mathrm{c}$ \\
\hline 40 & $14.2 \mathrm{a}$ & $20.3 b$ & $20.4 \mathrm{~b}$ & $25.5 \mathrm{c}$ \\
\hline 50 & $12.8 \mathrm{a}$ & $15.9 a b$ & $17.9 \mathrm{~b}$ & $23.4 \mathrm{c}$ \\
\hline 60 & $10.0 \mathrm{a}$ & $16.6 \mathrm{~b}$ & $19.2 \mathrm{~b}$ & $27.9 \mathrm{c}$ \\
\hline 70 & $10.0 \mathrm{a}$ & $16.8 \mathrm{~b}$ & $17.7 \mathrm{~b}$ & $24.7 \mathrm{c}$ \\
\hline
\end{tabular}




\section{Table IV.}

Foliar concentrations of macro- and micronutrients for the sustained-deficit irrigations (SDI) and control at each phenological stage of mango trees (Spain).

\begin{tabular}{|c|c|c|c|c|c|c|c|c|c|}
\hline \multirow[t]{2}{*}{ Parameter } & $\mathrm{N}$ & $\mathrm{P}$ & $\mathrm{K}$ & $\mathrm{Ca}$ & $\mathrm{Mg}$ & $\mathrm{Fe}$ & $\mathrm{Zn}$ & $\mathrm{Mn}$ & $\mathrm{Cu}$ \\
\hline & \multicolumn{5}{|c|}{$(\%)$} & \multicolumn{4}{|c|}{$\left(\mathrm{mg} \cdot \mathrm{kg}^{-1}\right)$} \\
\hline \multicolumn{10}{|l|}{ Irrigation treatment } \\
\hline SDI-1 (33\% ETC) & $1.60 \mathrm{a}$ & $0.16 \mathrm{a}$ & $0.24 \mathrm{a}$ & $2.48 \mathrm{a}$ & $0.26 a b$ & $125 \mathrm{a}$ & $23 \mathrm{a}$ & $160 a b$ & $6 a$ \\
\hline SDI-2 (50\% ETC) & $1.66 \mathrm{a}$ & $0.14 \mathrm{a}$ & $0.23 a$ & $2.28 \mathrm{a}$ & 0.32 b & $141 \mathrm{a}$ & $18 \mathrm{a}$ & $118 \mathrm{a}$ & $6 a$ \\
\hline SDI-3 (75\% ETC) & $1.64 \mathrm{a}$ & $0.21 \mathrm{~b}$ & $0.25 a$ & $2.59 \mathrm{a}$ & $0.23 \mathrm{a}$ & $134 \mathrm{a}$ & $20 \mathrm{a}$ & $191 b$ & $6 a$ \\
\hline $\mathrm{C}-100\left(100 \% \mathrm{ET}_{\mathrm{C}}\right)$ & $1.61 \mathrm{a}$ & $0.17 a b$ & $0.24 \mathrm{a}$ & $2.53 \mathrm{a}$ & $0.25 a b$ & $125 \mathrm{a}$ & $20 \mathrm{a}$ & $145 a b$ & $6 a$ \\
\hline \multicolumn{10}{|l|}{ Phenological stage } \\
\hline Dormancy & $1.52 \mathrm{a}$ & $0.17 \mathrm{~b}$ & $0.25 a b$ & $2.12 \mathrm{a}$ & $0.20 \mathrm{a}$ & $123 b$ & $14 \mathrm{a}$ & $122 \mathrm{a}$ & $5 a b$ \\
\hline Flowering & $1.60 \mathrm{a}$ & $0.28 c$ & $0.21 \mathrm{a}$ & $2.48 a b$ & $0.25 a b$ & $62 \mathrm{a}$ & $15 \mathrm{a}$ & $171 \mathrm{a}$ & $4 a$ \\
\hline Fruit set & $1.74 \mathrm{~b}$ & $0.16 \mathrm{~b}$ & $0.23 a$ & $2.60 \mathrm{~b}$ & $0.34 \mathrm{c}$ & $129 \mathrm{~b}$ & $21 a b$ & $162 \mathrm{a}$ & $7 \mathrm{bc}$ \\
\hline Fruit growth & $1.74 \mathrm{~b}$ & $0.14 a b$ & $0.25 a b$ & $2.66 \mathrm{~b}$ & $0.32 \mathrm{bc}$ & $173 \mathrm{c}$ & $27 \mathrm{~b}$ & $159 \mathrm{a}$ & $9 \mathrm{c}$ \\
\hline Harvest & $1.53 \mathrm{a}$ & $0.10 \mathrm{a}$ & $0.30 \mathrm{~b}$ & $2.51 \mathrm{ab}$ & $0.22 \mathrm{a}$ & $169 \mathrm{bc}$ & $23 a b$ & $154 \mathrm{a}$ & $7 b c$ \\
\hline \multicolumn{10}{|l|}{ Year } \\
\hline 2007 & $1.64 \mathrm{a}$ & $0.19 a$ & $0.26 \mathrm{a}$ & $2.61 \mathrm{a}$ & $0.25 \mathrm{a}$ & $86 a$ & 19 a & $161 \mathrm{a}$ & $6 a$ \\
\hline 2008 & $1.62 \mathrm{a}$ & $0.14 b$ & $0.21 \mathrm{~b}$ & $2.33 \mathrm{~b}$ & $0.28 \mathrm{a}$ & $177 \mathrm{~b}$ & $21 a$ & $146 \mathrm{a}$ & $7 a$ \\
\hline
\end{tabular}

Different letters within the same column are statistically different by Tukey's test $(p<0.05)$.

to $1.60 \%$, which was considered adequate by Young and Koo, who established an interval of $1.0 \%$ to $1.5 \%$ [33].

With respect to the phosphorus concentration, the irrigation treatment had a significant effect $(p<0.05)$, being higher in leaves of trees of the SDI- 3 treatment $(0.21 \%)$ than in the remaining treatments (table IV). The phenological stage also significantly influenced $\mathrm{P}$ concentrations, being higher for flowering than at the previous stage (dormancy). Higher $\mathrm{P}$ concentrations during flowering may be related to the formation of nucleic acids, proteins and coenzymes, fundamental for respiration, photosynthesis and glycolysis during the reproductive process [32]. Phosphorus concentrations declined during the fruit-set and fruit-growth stages; similar results were reported by Durán et al. [34], with values being lowest at harvest. The $\mathrm{P}$ concentration during our study period was within the interval of $0.08 \%$ to $0.18 \%$ recommended by Reuter and Robinson [35].

The leaf foliar potassium concentrations were not affected by the irrigation treatments $(p>0.05)$ (table IV). According to the phenological stage, potassium concentrations in dormancy were higher than in the subsequent stages (flowering and fruit set), due to post-harvest recuperation, as pointed out by Avilan [31]. The fall in $\mathrm{K}$ concentration during flowering agrees with the results of Avilan [31], Sergent et al. [36], and Durán et al. [34]. During fruit set and fruit growth, the $\mathrm{K}$ concentrations remained relatively low, due to the $\mathrm{K}$ demand during fruit development and its translocation from the leaves to the fruit through the phloem, according to Mukherjee [37]. After harvest, potassium concentrations began to recover, as was indicated by Durán et al. [34], probably due to the lighter fruit load in this period. Finally, the $\mathrm{K}$ concentrations in our study ranged from $0.21 \%$ to $0.30 \%$, values considered low by Guimaräes et al., who established an adequacy interval of $1.0-1.2 \%$ [38].

The leaf calcium concentrations did not significantly differ according to the irrigation treatment applied; however, a decreasing trend was found in dormancy, as was also pointed out by Durán et al. [34]. By contrast, 
the magnesium concentrations were significantly higher in leaves of trees of the SDI2 treatment than in the rest of the treatments $(p<0.05)$ and were lowest during dormancy and at harvest $(0.20 \%$ and $0.22 \%$, respectively). Both the $\mathrm{Ca}$ and $\mathrm{Mg}$ concentrations increased again during fruit set and fruit growth, in accord with Pathak and Pandey [39], and Janse van Vuuren and Stassen [40]. In our experiment, the Ca concentrations were very similar to those found by Guzmán et al. [41] for mango cv. Manila, with the highest $\mathrm{Ca}$ concentrations after harvest and during fruit set.

On the other hand, the leaf iron concentration was not affected significantly by the irrigation treatment (table IV). Nevertheless, the Fe foliar concentration varied considerably for each phenological stage in all treatments. The Fe concentration proved to be significantly higher during fruit growth and harvest [(173 and 169$) \mathrm{mg} \cdot \mathrm{kg}^{-1}$, respectively] and was lowest during flowering; these results are in agreement with those of Guzmán et al. [41]. However, the Fe concentrations for our experiment were higher than $50 \mathrm{mg} \cdot \mathrm{kg}^{-1}$, a lower limit considered as deficient [42].

The leaf manganese concentration was significantly affected by the irrigation treatment, being highest for the trees of the SDI3 treatment, followed by those of the SDI-1, C-100 and SDI-2 treatments [191, 160, 145 and 118$) \mathrm{mg} \cdot \mathrm{kg}^{-1}$, respectively] (table IV). By contrast, the effect of the phenological stage was not significant, although there was a trend toward slightly higher values during flowering, fruit set and fruit growth. The highest Mn concentration was found by Guzmán et al. for cv. Manila, also during flowering [41]. This was due presumably to the translocation of $\mathrm{Mn}$ via the phloem to meristem tissues [43]. Mutual interference was found between Fe and Mn, the Fe concentration being minimum during flowering and fruit set, whereas, in this period, Mn concentrations reached their maximum. This trend was also reported for other plant species [44]. Manganese levels in all treatments fell below the maximum recommended $\left(250 \mathrm{mg} \cdot \mathrm{kg}^{-1}\right)$ [42].

The leaf zinc and copper concentrations were not affected by the irrigation treatment and both had similar trends. Concentrations were lowest during dormancy and flowering and highest during fruit growth and harvest (table IV). The leaf $\mathrm{Cu}$ level fell at flowering $\left(4 \mathrm{mg} \cdot \mathrm{kg}^{-1}\right)$, differing significantly $(p<0.05)$ from most of the phenological stages, and this decrease could be explained by the translocation from the mature leaves to the young ones [45] and towards the flowers, which are extremely dependent on this micronutrient [46]. On the other hand, according to Guzmán et al. [41], both $\mathrm{Cu}$ and $\mathrm{Zn}$ are concentrated in the seed during fruit growth, this favouring a fall in the levels of both elements in other organs, such as leaves, during this period. The wellknown antagonism between $\mathrm{P}$ and $\mathrm{Zn}$ was detected throughout our study period, except for dormancy. In our study, copper concentrations presented levels below the recommended $10 \mathrm{mg} \cdot \mathrm{kg}^{-1}$ and $\mathrm{Zn}$ concentration was low [42], although above $10 \mathrm{mg} \cdot \mathrm{kg}^{-1}$, a level considered totally deficient [47].

Thus, according to our results, the nutrient status was not affected by sustained-deficit irrigation at all, with the exception of $\mathrm{P}$, $\mathrm{Mg}$ and Mn.

Control trees produced the greatest fruit length and width [(14.1 and 9.5) cm, respectively] (table I), differing significantly from the other treatments, in accordance with the fruit weight. On the contrary, the SDI- 1 treatment produced the smallest fruits [(13.1 and 8.6) $\mathrm{cm}$, respectively].

The results of the weight percentage for skin, pulp and seed for sustained-deficit irrigation and control treatments and for the last two seasons (2007 and 2008) showed that the skin weight percentage ranged from $9.3 \%$ to $11.3 \%$ and from $6.9 \%$ to $8.2 \%$ for 2007 and 2008, respectively (table V). However, skin weight did not significantly differ between treatments, and our results were slightly lower than those of Laborem et al. for cvs. Manzana, Gleen and Zill (10.217.9\%) [48] and those of Singh [49] with cv. Filipinas (11-18\%). In relation to the pulp weight, percentages ranged from $84.7 \%$ to $86.3 \%$ and from $86.1 \%$ to $88.5 \%$, for 2007 and 2008, respectively. Our pulp weight percentages for $\mathrm{cv}$. Osteen surpassed those of Laborem et al. with cvs. Manzana, Gleen and 
Table V.

Characteristics of mango fruits during two growing seasons (2007 and 2008) for sustained-deficit irrigations (SDI) and control trees (Spain).

(a) 2007 growing season

\begin{tabular}{|c|c|c|c|c|c|}
\hline Irrigation treatment & $\begin{array}{l}\text { Skin } \\
(\%)\end{array}$ & $\begin{array}{c}\text { Seed } \\
(\%)\end{array}$ & $\begin{array}{l}\text { Pulp } \\
\text { (\%) }\end{array}$ & $\begin{array}{l}\text { Total soluble solids } \\
\text { ('Brix) }\end{array}$ & $\begin{array}{l}\text { Titratable acidity } \\
\text { (\% of citric acid) }\end{array}$ \\
\hline SDI-1 $\left(33 \% \mathrm{ET}_{\mathrm{C}}\right)$ & $10.1 \mathrm{a} \pm 0.7$ & $4.2 a \pm 0.7$ & $85.7 \mathrm{a} \pm 1.2$ & $18.8 \mathrm{a} \pm 0.5$ & $0.45 a \pm 0.2$ \\
\hline SDI-2 (50\% ET $)$ & $10.3 a \pm 1.4$ & $4.3 a \pm 0.5$ & $85.4 \mathrm{a} \pm 1.0$ & $17.6 a b \pm 0.4$ & $0.32 \mathrm{a} \pm 0.1$ \\
\hline SDI-3 (75\% ETC) & $9.3 \mathrm{a} \pm 1.0$ & $4.4 \mathrm{a} \pm 0.6$ & $86.3 a \pm 0.8$ & $16.6 a b \pm 1.3$ & $0.46 a \pm 0.2$ \\
\hline C-100 (100\% ETC) & $11.3 a \pm 1.6$ & $4.0 a \pm 0.5$ & $84.7 \mathrm{a} \pm 1.5$ & $15.4 b \pm 0.8$ & $0.44 a \pm 0.1$ \\
\hline \multicolumn{6}{|c|}{ (b) 2008 growing season } \\
\hline Irrigation treatment & $\begin{array}{l}\text { Skin } \\
(\%)\end{array}$ & $\begin{array}{l}\text { Seed } \\
(\%)\end{array}$ & $\begin{array}{l}\text { Pulp } \\
(\%)\end{array}$ & $\begin{array}{l}\text { Total soluble solids } \\
\text { ('Brix) }\end{array}$ & $\begin{array}{l}\text { Titratable acidity } \\
\text { (\% of citric acid) }\end{array}$ \\
\hline SDI-1 (33\% ETC) & $8.2 \mathrm{a} \pm 1.6$ & $5.7 \mathrm{a} \pm 1.5$ & $86.1 \mathrm{a} \pm 1.5$ & $17.8 \mathrm{a} \pm 1.3$ & $0.21 \mathrm{a} \pm 0.1$ \\
\hline SDI-2 (50\% ETC) & $8.3 \mathrm{a} \pm 1.8$ & $4.7 \mathrm{a} \pm 1.0$ & $87.1 \mathrm{a} \pm 2.8$ & $17.3 \mathrm{a} \pm 1.7$ & $0.25 a \pm 0.0$ \\
\hline SDI-3 (75\% ETC) & $7.5 a \pm 0.9$ & $5.6 a \pm 0.6$ & $86.9 a \pm 0.9$ & $17.0 \mathrm{a} \pm 1.3$ & $0.21 \mathrm{a} \pm 0.1$ \\
\hline C-100 (100\% ETC) & $6.9 \mathrm{a} \pm 1.2$ & $4.6 \mathrm{a} \pm 0.5$ & $88.5 a \pm 0.8$ & $16.6 \mathrm{a} \pm 0.7$ & $0.21 \mathrm{a} \pm 0.0$ \\
\hline
\end{tabular}

Zill (67.3-77.9\%) [48]. Taking into account the two years, we detected differences for the [pulp : seed] ratio, which had the following pattern: $\mathrm{C}-100>$ SDI-2 $=$ SDI-3 $>$ SDI- 1 (22.5, 19.9, 18.4 and 16.8, respectively) $(p<0.05)$. In general, differences in the weight percentage of skin, pulp and seed were not affected by the irrigation treatment, since these parameters are normally more related to the variety of mango itself than to any other factors.

In 2007, differences in total soluble solids (TSS) of mango fruits were statistically significant $(p<0.05)$ according to the three irrigation treatments, being highest in the SDI-1 treatment, indicating a possible active sugar accumulation due to the lower amount of irrigation (table $V$ ). These results have also been reported for mango fruits by Spreer et al. [24]. Also, this trend: SDI-1 > SDI-2 $>$ SDI-3 $>$ control in TSS was recorded in 2008, although differences were not significant. The recorded values for TSS in our experiment agree with those found by Dick et al. for cv. Kent, which varied from (14.2 to 20$)^{\circ}$ Brix [50]. In addition, during 2008 , the skin weight percentage was slightly higher in the fruits of trees of the SDI- 1 and SDI-2 treatments than in those of the SDI-3 treatment and control. The titratable acidity was not significantly affected by the irrigation treatment. In addition, the highest and lowest values of the [TSS : TA] ratio were found for fruits of the SDI-1 (84.8) and SDI-2 (69.2) treatments. The water percentage for the different parts of the fruit differed statistically $(p<0.05)$ : seed $(45 \%)>\operatorname{skin}(60 \%)=$ seed $(65 \%)>$ pulp $(78 \%)$. These results were very similar to those reported by Guzmán et al. for mango cv. Manila [51].

According to Avilan et al. [52], the ideal mango fruit has a high [pulp : seed] ratio, good firmness, appropriate consistency, absence of fibre, and an adequate [sugar : acidity] ratio. The [pulp : seed] and [sugar : acidity] ratios of mango fruits cv. Osteen were not significantly affected by the SDI treatments, which is making it one of the most valuable adapted commercial cultivars on the Granada coast, as pointed out by Durán et al. [5, 21]. Thus, mango cultivation in south-eastern Spain shows 
promising possibilities to offer high-quality fresh fruits to the European consumer, especially given the proximity of other EU countries.

\section{Conclusion}

Our results demonstrated that the amount of irrigation in mango is important in order to improve the water-saving strategies for sustainable subtropical agriculture in orchard terraces. In the mango tree orchards studied, the highest yield and water-use efficiency were obtained with the SDI-2 treatment $\left(50 \%\right.$ of $\left.\mathrm{ET}_{\mathrm{C}}\right)$, and thus the greatest amounts of water did not result in the highest yield. In addition, yield was strongly correlated with the number of fruits and not with fruit size. The average fruit size was larger for mango from the SDI- 3 treatment $\left(100 \% \mathrm{ET}_{\mathrm{C}}\right)$ and control trees, with length and width being significantly greater than fruit of other treatments. Significant second-degree polynomial relationships between mango fruit yield and irrigation were found. On the other hand, the nutrient status of the mango tree was not affected by sustained-deficit irrigation strategies, except for $\mathrm{P}, \mathrm{Mg}$ and $\mathrm{Mn}$. Therefore, the decrease in surface-soil moisture through irrigation did not affect the mineral uptake by mango trees. Thus, according to the results of the present experiment, the sustained deficit-irrigation treatment with $50 \%$ of $\mathrm{ET}_{\mathrm{C}}$ should be adopted as the most appropriate irrigation strategy for achieving sustainable, efficient water management in mango orchards under a Mediterranean subtropical climate.

\section{Acknowledgements}

The research work that led to this publication was sponsored by the research project "Environmental impact of farming subtropical species on steeply sloping lands. Integrated measures for sustainable agriculture" (RTA05-00008-00-00), funded by INIA, Spain, and cofinanced by FEDER funds (European Union).

\section{References}

[1] Anon., Statistics, FAOSTAT, Food and Agriculture Organization of the United Nations, Rome, Italy, 2008.

[2] Anon., Mangos, Market Bulletin, Tanzania Agriculture Productivity Program, USAIDTAPP, Tanzania, issue 1, August 2010, 5 p.

[3] Anon., Fresh fruit and vegetables: The EU market for mango, Centre for the Promotion of Imports from Developing Countries, CBI Market Information Database, 2009, 15 p. (www.cbi.eu).

[4] Campbell R.S., Campbell C.N., Commercial Florida cultivars, Acta Hortic. 341 (1993) 5559.

[5] Durán Zuazo V.H., Martínez A., Aguilar J., Tarifa D.F., El cultivo del mango (Mangifera indica L.) en la costa granadina, Durán Z.V.H. (Ed.), Granada, Spain, 2003, 142 p.

[6] Calatrava R.J., González R.M.C., Guirado S.E., Mateo S.J., Descriptores de frutos en cultivares de mangos existentes en España: Caracterización morfológica y comercial, Junta de Andalucía C.A.P., Serie Información Técnica 15/92, Sevilla, Spain, 1993.

[7] English M., Raja S.N., Perspectives on deficit irrigation, Agric. Water Manag. 32 (1996) $1-14$.

[8] Fereres E., Soriano M.A., Deficit irrigation for reducing agricultural water use, J. Exp. Bot. 58 (2007) 147-159.

[9] Lechaudel M., Joas J., Caro Y., Genard M., Jannoyer M., Leaf:fruit ratio and irrigation supply affect seasonal changes in minerals, organic acids and sugars of mango fruit, $\mathrm{J}$. Sci. Food Agric. 85 (2005) 251-260.

[10] Anon., Soil survey staff, soil taxonomy. A basic system of soil classification for making and interpreting soil surveys, USDA, Agric. Handbook, No. 436, USA, 1999.

[11] Anon., Métodos Oficiales de Análisis. Tomo III, Secr. Gen. Téc. Minist. Agric. Pesca Aliment. (MAPA), Madrid, Spain, 1994.

[12] Allen R.G., Pereira L.S., Raes D., Smith M., Crop evapotranspiration (guidelines for computing crop water requirements), FAO Irrigation and Drainage, Pap. $\mathrm{N}^{\circ} 56, \mathrm{FAO}$, Rome, Italy, 1998.

[13] Durán Zuazo V.H., Rodríguez P.C.R., Tarifa D.F., Monitoring the pollution risk and water use in orchard terraces with mango and 
cherimoya trees by drainage lysimeters, Irrig. Drain. Syst. (2011) (in revision).

[14] Anon., Official methods of analysis of the Association of Official Analytical Chemists, AOAC, 14th ed., Arlington, VA, USA, 1980.

[15] Avilán R.L., Rodríguez M., Ruíz J., Marín C.R., Selección de patrones de bajo porte en mango, Agron. Trop. 47 (1997) 259-270.

[16] Howell T.H., Cuenca R.H., Solomon K.H., Crop yield response, in: Hoffman, G.J., Howell T.A., Solomon K.H. (Eds.), Management of farm irrigations, systems, ASAE, Monogr., USA, 1990, 93-116.

[17] Chapman H.D., Pratt P.F., Method of analysis for soils, plants and waters, Univ. Calif. (Riverside), Berkeley, USA, 1961.

[18] Fiske S., The colorimetric determination of phosphorus, J. Biol. Chem. 66 (1952) 375400.

[19] Bremner J.M., Total nitrogen, in: Black C.A. (Ed.), Methods of analysis, part. 2, Agronomy 9, Acad. Press, N.Y., USA, 1965, 1149-1178.

[20] Avilán R.L., Cuatro años de fertilización nitrogenada en mango (Mangifera indica L.) en suelos de la serie Maracay, Agron. Trop. 24 (1974) 97-106.

[21] Durán Zuazo V.H., Rodríguez P.C.R., Tarifa D.F., Fruit yield, growth and leaf-nutrient status of mango trees grafted on two rootstocks in a marginal growing area (South-East Spain), Fruits 61 (2006) 1-8.

[22] Spreer W., Ongprasert S., Hegele M., Wünsche J.N., Müller J., Yield and fruit development in mango (Mangifera indica L. Cv. Chok Anan) under different irrigation regimes, Agric. Water Manag. 96 (2009) 574-584.

[23] Pavel E.W., Villiers A.J.D., Responses of mango trees to reduced irrigation regimes, Acta Hortic. 646 (2004) 63-68.

[24] Spreer W., Nagle M., Neidhart S., Carle R., Ongprasert S., Müller J., Effect of regulated deficit irrigation and partial rootzone drying on the quality of mango fruits (Mangifera indica L., cv. 'Chok Anan'), Agric. Water Manag. 88 (2007) 173-180.

[25] da Campos J.H.B., da Silva V.P.R., de Azevedo P.V., Borges C.J.R., Soares J.M., de Moura, M.S.B., da Silva B.B., Evapotranspira ao e produtividade da mangueira sob diferentes tratamentos de irriga ao, Rev. Bras. Engen. Agríc. Ambient. 12 (2008) 150-156.
[26] Litz R.E., Mango-botany, production and use, CAB Int., Wallingford, U.K., 680 p., 2009.

[27] Sezen A.M., Yazar A., Eker S., Effect of drip irrigation regimes on yield and quality of field grown bell pepper, Agric. Water Manag. 81 (2006) 115-131

[28] Gattan S.R., Berenguer M.J., Connell J.H., Polito V.S., Vossen P.M., Olive oil production as influenced by different quantities of applied water, Agric. Water Manag. 85 (2006) 133-140.

[29] Ponchner S., Rojas R., Bornemisza E., Variación estacional de nutrimentos en árboles de mango (Mangifera indica) en tres suelos del Pacífico Seco de Costa Rica. I. Macronutrimentos, Agron. Costarric. 17 (1993) 21-30.

[30] Stassen P.J.C., Janse van Vuuren B.P.N., Seasonal uptake and utilization of nitrogen by 'Sensation' mango trees, Acta Hortic. 455 (1997) 351-358.

[31] Avilán R.L., Variaciones de los niveles de N, $\mathrm{P}, \mathrm{K}$ y Ca en las hojas de mango (Mangifera indica L.) a través de un ciclo de producción, Agron. Trop. 21 (1971) 3-10.

[32] Leopold A.C., Kriedemann P., Plant growth and development, McGraw-Hill, N.Y., USA, 1975.

[33] Young T.W., Koo R.C.J., Mineral composition of Florida mango leaves, Proc. Fla. State Hortic. Soc. 82 (1969) 324-328.

[34] Durán Zuazo V.H., Aguilar J., Martínez A., Fruit yield, plant growth and nutrient status in mango: effect of rootstocks, Int. J. Fruit Sci. 5 (2005) 3-21.

[35] Reuter D.J., Robinson J.B., Plant analysis: an interpretation manual. Fruits, vines and nuts, Inkata Press, Melbourne, Australia, 1986.

[36] Sergent E., Leal F., Casanova E., Niveles foliares de NPK en mango (Mangifera indica L.), Rev. Fac. Agron. 19 (1993) 319-328.

[37] Mukherjee S.K., Current advances on mango research around the world. Tropical and subtropical fruits, Acta Hortic. 57 (1976) 37-42.

[38] Guimarães P., Nutricao e adubacao da mangueira, Inf. Agropecu. 8 (1982) 28-35.

[39] Pathak R.A., Pandey R.M., A note on the status of mineral content of inflorescence and fruits at different of their growth in mango (Mangifera indica L. CV. Dashehari), Ind. J. Plant Physiol. 20 (1977) 41-43. 
[40] Janse van Vuuren B.P.H., Stassen P.J.C., Seasonal uptake of macro elements by young bearing 'Sensation' mango trees, Acta Hortic. 455 (1977) 167-174.

[41] Guzmán E.C., Mosqueda V.R., Alcalde B.S., Martínez G.A., Macro and micronutrient foliar content variation in mango cv. Manila, Acta Hortic. 455 (1977) 471-478.

[42] Jones J.B., Wolf B., Mills H.A., Plant analysis handbook: a practical sampling, preparation, analysis, and interpretation guide, Micro-macro Publ. Inc., Athens, GA, U.S.A., 1991.

[43] Tiffin L.O., Translocation of micronutrients in plants, in: Mortvedt J.J., Giordano P.M., Linsay W.L. (Eds.), Micronutrients in agriculture, Soil Sci. Soc. Am. Inc., Madison, U.S.A., 1972, 199-229.

[44] Roomizadeh S., Karimian N., Manganeseiron relationship in soybean grown in calcareous soils, J. Plant Nutr. 19 (1996) 397-406.

[45] Loneragan J.F., The availability and absorption of trace elements in soil-plant system and their relation to movement and concentrations of trace elements in plants, in: Nicholas D.J.D., Egan A.R. (Eds.), Trace ele- ments in soil-plant systems, Acad. Press, Lond., U.K., 1975, 109-134.

[46] Mills H.A., Jones J.B., Plant analysis handbook II, A practical sampling, preparation, analysis and interpretation guide, MicroMacro Publ. Inc., Athens, GA, U.S.A., 1996.

[47] Mengel K., Kirkby E.A., Principles of plant nutrition, 4th ed., Int. Potash Inst., Berna, Switz., 1987.

[48] Laborem G., Avilán R.L., Figueroa M., Extracción de nutrientes por una cosecha de mango (Mangifera indica L.), Agron. Trop. 29 (1979) 3-15.

[49] Singh L.B., The mango. Its botany, cultivation and utilization, World Crops Ser. Book, Leonard Hill. Lond., U.K., 1960.

[50] Dick E., Adopo N.A., Camara B., Moudioh E., Influence of maturity stage of mango at harvest on its ripening quality, Fruits 64 (2009) 13-18.

[51] Guzmán E.C., Alcalde B.S., Mosqueda V.R., Martínez G.A., Contenido y extracción de algunos nutrimentos por el fruto de mango cv. Manila, Agron. Trop. 46 (1996) 431-446.

[52] Avilan R.L., Rodríguez M., Ruiz J., El cultivo del manguero en Venezuela, FONAIAP Ed., Maracay, Venez., 1998.

\section{Impacto del riego deficitario sostenido en el crecimiento del árbol, nutrición mineral, producción y calidad del mango en España.}

Resumen - Introducción. El cultivo del mango (Mangifera indica L.) tiene un importancia económica importante en las provincias de Málaga y Granada (SE España). Fue diseñado un experimento de campo con árboles de mango para determinar la programación óptima de riego, durante tres temporadas. El objetivo fue evaluar el impacto de estrategias de riego deficitario sostenido (SDI) en la producción de frutos y calidad, crecimiento del árbol y el estado nutricional bajo condiciones de clima subtropical mediterráneo. Materiales y métodos. Tres tratamientos de riego deficitario sostenido fueron aplicados en árboles del mango: SDI-1 (33\% $\left.\mathrm{ET}_{\mathrm{C}}\right)$, SDI-2 $\left(50 \% \mathrm{ET}_{\mathrm{C}}\right)$ y SDI-3 $\left(75 \% \mathrm{ET}_{\mathrm{C}}\right)$. Los tres tratamientos estresados fueron comparados con un control (C-100) regado al 100\% $\mathrm{ET}_{\mathrm{C}}$. La respuesta de la producción, número de frutos, tamaño del fruto y calidad, y niveles foliares en macro y micronutrientes fueron determinados. Resultados. El SDI-2 demostró ser el más apropiado entre los tratamientos SDI, permitiendo que los árboles alcancen el máximo rendimiento (18.4 t $\cdot \mathrm{ha}^{-1}$ ) y la mejor eficiencia del uso del agua $\left(7.14 \mathrm{~kg} \cdot \mathrm{m}^{-3}\right)$. Sin embargo, el tamaño del fruto fue mayor en árboles de los tratamientos SDI-3 y C-100, alcanzando valores significativamente altos de longitud y anchura. Los solutos solubles totales fueron afectados por los tratamientos de SDI durante el primer año, con valores altos en los frutos de los árboles de los tratamientos SDI-1 y SDI-2. Los niveles foliares de macro y micronutrientes fueron alterados por los tratamientos SDI solo en los contenidos de P, Mg y Mn. Conclusión. El tratamiento SDI que proporciona el 50\% de $\mathrm{ET}_{\mathrm{C}}$ es recomendado para obtener el máximo rendimiento y uso eficiente del agua de riego en cultivos del mango bajo clima subtropical mediterráneo.

España / Mangifera indica / riego / uso del agua / déficit de humedad en el suelo / dosis de riego / frutas / crecimiento / nutrición de las plantas / rendimiento / calidad 